May 2013

\title{
Demonstrating the Value of the Public Library: Economic Valuation and the Advocacy Imperative
}

Tracy L. Micka

San Jose State University, School of Library and Information Science, mickatracy@gmail.com

Follow this and additional works at: https://scholarworks.sjsu.edu/ischoolsrj

Part of the Library and Information Science Commons

\section{Recommended Citation}

Micka, T. L. (2013). Demonstrating the Value of the Public Library: Economic Valuation and the Advocacy Imperative. School of Information Student Research Journal, 3(1). https://doi.org/10.31979/ 2575-2499.030104 Retrieved from https://scholarworks.sjsu.edu/ischoolsrj/vol3/iss1/4

This article is brought to you by the open access Journals at SJSU ScholarWorks. It has been accepted for inclusion in School of Information Student Research Journal by an authorized administrator of SJSU ScholarWorks. For more information, please contact scholarworks@sjsu.edu. 


\title{
Demonstrating the Value of the Public Library: Economic Valuation and the Advocacy Imperative
}

\author{
Abstract \\ Promising developments in the field of library valuation over the last fifteen years are providing new \\ options for demonstrating library value. Metrics-gathering has moved away from counting inputs and \\ outputs toward measuring the value of the public library in monetary terms using increasingly \\ sophisticated quantitative methods formerly reserved for business and industry. While it is premature to \\ draw a firm conclusion as to the impact of economic valuation efforts on the success of library advocacy, \\ the adoption of private sector concepts represents a new window of opportunity for library advocates. \\ This critical review synthesizes the library valuation literature, exploring the various frameworks through \\ which library value is being articulated, and finds that econometrics will be most useful to advocates \\ when: 1) library valuation efforts are united with advocacy plans; 2 ) library services are linked to the \\ achievement of public policy goals; and 3) public libraries are able to connect to a wider funding base.

\section{Keywords} \\ public libraries, libraries - evaluation, libraries - economic aspects, library administration

\section{About Author} \\ Tracy Micka is a graduate student at San José State University, School of Library and Information Science \\ and holds a BA in Sociology from the University of California San Diego.
}


Libraries exist within a vexing duality: they enjoy enormous public support (even non-users recognize them as valuable community assets, convinced that every town should have a library) yet, when it comes down to the ballot box, taxpayers will often choose to fund schools, police, or fire departments over the public library. Only the parks and recreation department garners less funding support (De Rosa \& Johnson, 2008). The American public likes the idea of having a library, but does not appear to view it as an essential public service (De Rosa \& Johnson, 2008; Hughes, 2009). Unfortunately, library advocates have long relied on this tenuous support base, failing to demonstrate in a meaningful way why every town should have a library (Jaeger, Bertot, Kodama, Katz, \& DeCoster, 2011). More than ever, library administrators are under pressure to demonstrate the socio-economic value of the library. The sustained worldwide economic crisis and the resultant budget-slashing make this mandate urgent. Promising developments in the field of library valuation over the last fifteen years may provide advocates with new options for demonstrating library value. During this timeframe, metrics-gathering has moved away from counting inputs and outputs toward measuring the value of public libraries in monetary terms using increasingly sophisticated quantitative methods formerly reserved for business and industry (Imholz \& Arns, 2007).

Tracing the trajectory of economic valuation in public libraries, this paper reveals a path that began with the desire to communicate library value in monetary terms, and wound up making the case for evidence-based, impactcentric advocacy. With the aim of assessing how economic valuation can help library advocates be more successful, the paper identifies the likely macro-drivers of the trend toward econometrics, summarizes the new methods, and explores the various frameworks through which library value is being assessed. While it is still too early to draw a firm conclusion as to the impact of library economic valuation efforts on the success of library advocacy, the adoption of private sector concepts represents a new window of opportunity to quantify the value, showcase the relevance, and justify the continued existence of the public library, in good times and in bad.

\section{Literature Review}

The literature review for this paper focused on public library valuation efforts, and as such, excluded much, though not all, of the academic and special library valuation literature. By no means was this a decision of convenience meant to avoid investigation into the prolific literature and professional activity related to the "value of the academic library." It is clear that academia is concerned with 
demonstrating the value of their libraries and has produced important studies, ${ }^{1}$ convened groundbreaking conferences, ${ }^{2}$ and has otherwise been instrumental in furthering the cause of library valuation. However, while public and academic libraries have shared a similar valuation trajectory, and very often work toward many of the same goals, public libraries stand more on their own and are not tied to the mission of a university and its success in the way that academic libraries are. As such, it was decided that the public library literature would be more instructive, a decision that also yielded an interesting connection between public access computing and library valuation.

Public library valuation studies range from professional reports conducted at the branch level to major national and multi-country investigations. For the purposes of this paper, overviews and meta-analyses conducted in a scholarly fashion were selected for their ability to sift, sort, and make sense of the smaller individual studies. The most notable work in this category is the Americans for Libraries Council's Worth Their Weight: An Assessment of the Evolving Field of Library Evaluation, a report underwritten by the Bill \& Melinda Gates Foundation (Imholz \& Arns, 2007). In addition, various professional handbooks were selected, including The PLA Reader for Public Library Directors and Managers (Hughes, 2009) to gain perspective on the kind of evaluation instruction that working professionals might use. The economics literature, particularly in the environmental economics area, was consulted for information on new valuation techniques. Finally, some of the more recent reports on the impact of public access computing were reviewed, notably the 2010 U.S. Impact Study conducted by the University of Washington's Information School with a grant from the Institute of Museum and Library Services (IMLS) and the Bill \& Melinda Gates Foundation (Becker et al., 2010). A handful of subject experts writing in scholarly journals, speaking at conferences, and musing in blogs provided important contextual analysis of the library valuation environment. This paper synthesizes the library valuation literature reviewed by the author, and is part of the ongoing search for effective library advocacy tools that will bring to light the true value of the public library, one of America's most prized social institutions.

\section{Drivers of the Shift to Econometrics}

Throughout the library community, it is increasingly understood that the old paradigm of reporting inputs and outputs, such as collection cost numbers and

\footnotetext{
${ }^{1}$ Currently, the most influential study is Lib-Value, a multi-year project that aims to provide a suite of models for measuring Return-on-Investment (ROI) in academic libraries.

2 The Library Assessment Conference has been running since 2006 at the behest of the Association of Research Libraries (ARL).
} 
circulation statistics, can neither capture the full value of the public library to its community, nor tell a story compelling enough to grab the attention of policymakers. There is widespread recognition that a new policy environment exists, one in which "talking dollars makes sense" (Imholz \& Arns, 2007, p. 7). Why is the public library's value being measured in new ways, and what is driving the shift to a more comprehensive valuation framework capable of assessing the library's contribution to society in terms of economic value? The macro-drivers of this trend include economic pressures in the public sector, demand for greater institutional accountability, and new methodologies in the field of environmental economics.

\section{Economic Pressures in the Public Sector}

While public libraries have long been sensitive to the voting public's financial situation, given that their primary source of funding comes from taxpayers (Aab $\varnothing$, 2009), the sustained economic crisis we find ourselves in today means that tax dollars are more heavily guarded than ever and are subject to even greater scrutiny. Dependent largely on the willingness of local government officials to put library funding on the ballot in the first place, or to make a general fund allocation, public libraries are recognizing the need to tailor their funding messages to the pressing interests of local government. In an era of increased competition for public funds, this comes down to the bottom line. Local officials want to know: What is the net return on this investment? Why should we fund libraries instead of the fire department, the police, schools, or parks \& recreation? Cost-benefit-analysis, return-on-investment, and other dollars-andcents valuation methods used in the private sector go a long way toward making a concrete and succinct financial argument for public libraries in a way that circulation statistics and number of public computers never will. Aabø (2009) provides a clear example of this type of financial argument: In her meta-analysis of 38 library valuation studies that used cost-benefit-analysis and return-oninvestment, Aabø concluded that for each dollar spent on library services, the community receives four dollars in benefits. This is a compelling argument, and one that more libraries are endeavoring to make.

\section{Call for Greater Institutional Accountability}

In parallel to the growing primacy of the language of business, there has been increasing pressure for greater institutional accountability in the public sector. An important historical precedent to more stringent accountability standards in the U.S. came from the 1993 Government Performance and Results Act (GPRA), a federal initiative requiring measureable performance goals and the demonstration 
of impacts instead of efficiency (Bertot, 2006; Durrance \& Fisher-Pettigrew, 2002). The effects of GPRA were felt throughout the public library system as local libraries began to develop new ways of demonstrating the impacts of their programs and services in order to win federally-funded, state-allocated grants (Bertot, 2006).

By the turn of the millennium, traditional library performance indicators were giving way to library impact planning and assessment initiatives. Streatfield (2012) identifies this gradual shift from the primary goal of performance measurement toward the more "ambitious" goal of evaluating impact (p. 9) in his outline of the history of the Bill \& Melinda Gates Foundation's Global Library Initiative. Streatfield points to new evidence collection methods, such as contingent valuation, ${ }^{3}$ as an emergent way to collect perceptions of the economic value of the library. The idea of evidence-based policy and practice (EBPP), the methodical process of gathering and analyzing impact evidence, as a guiding principle for better service delivery had taken hold in the healthcare, education, and social work areas (Markless \& Streatfield, 2006). Now library and information science has, in turn, been investigating the ideas of EBPP as a practice model, and in doing so, is beginning to consider an evidence-based framework as a means for demonstrating accountability.

\section{New Methods from the Field of Environmental Economics}

Authors of library valuation studies have historically used standard economic valuation methods such as cost-benefit-analysis (CBA) and return-on-investment (ROI) to make their case, but the library valuation field now is experiencing an increasing complexity in methods. ROI and CBA are giving way to a fuller accounting that expresses the total social and cultural value of libraries to our communities with methods that can put an exact value on intangible, non-market goods (Imholz \& Arns, 2007). For example, it can be difficult to assign a monetary value to the library's role in developing what the Institute of Museum and Library Services (IMLS) calls " 21 st century skills": "information, communications and technology literacy, critical thinking, problem solving, creativity, civic literacy, and global awareness" (IMLS, n.d.). These are areas where libraries excel but have, until recently, have been difficult to value.

Through the use of Social return-on-investment (SROI), these areas can be fully accounted for. SROI is an analytic tool that accounts for the social, cultural, and environmental impacts of a project, program, or organization. SROI can assign monetary value to such impacts thereby transforming these intangible impacts into visible, and therefore measureable, values. SROI has been used extensively in environmental economics to capture the unseen costs associated

\footnotetext{
${ }^{3}$ For more information on contingent valuation, refer to The Valuation Methods section.
} 
with the degradation of the natural world. Such social, cultural and environmental impacts have long been viewed as "externalities," or " loss[es] or gain[s] in the welfare of one party resulting from an activity of another party" (Externalities, n.d.). ${ }^{4}$

Defining externalities in terms of social welfare gains is key to understanding how important SROI could be to library valuation efforts, given that much of what the library does generates positive externalities/social welfare gains (Imholz \& Arns, 2007). For example, toddler story time contributes to the early education of preschoolers and public access computers and trained librarians enable adults to apply for jobs on-line, which improves the economic health of the local community. The demand for evidence of the library's value-add capabilities has library managers and researchers considering these new valuation techniques in an effort to clarify the often nebulous and hard-to-capture nature of the library's social impact. 5

\section{Terms and Explanation of the Valuation Methods}

Historically, the field of library valuation is full of slippery language and muddled terminology. The terms Assessment, Evaluation, Valuation and Measurement have all been used interchangeably to indicate the library management practice of gathering evidence to demonstrate the effects of the library, or "to tell a story with data." Typically, however, library valuation is specific to studies that measure the impact of the library and use monetary value as the primary metric, having evolved from the wider field of library management and economics (Aabø, 2009), while library assessment, evaluation, and measurement developed more from the performance and benchmarking areas of library management which focuses on efficient service delivery, using metrics that demonstrate how the library provides the most services (outputs) with the least amount of labor and technology/infrastructure costs (inputs) (Markless \& Streatfield, 2006). Library measurement has evolved from counting inputs and outputs that lead to predetermined outcomes, such as user satisfaction, number of cardholders, or system efficiency, to quantifying the (often abstract) value of libraries to individuals and

\footnotetext{
4 An example of a "negative externality" is pollution emitted by a factory that spoils the surrounding environment and adversely affects the heath of nearby residents. An example of a "positive externality" is the effect of a well-educated labor force on the productivity of a company. (Externality, n.d.)

${ }^{5}$ On a related note, the balanced scorecard, often cited as a form of SROI, but really more of a performance indicator, may be useful in library valuation because of its underlying assumption that no one measure (such as circulation statistics) can adequately encapsulate the reach and impact of the library. (Brophy, 2006; Imholz \& Arns, 2007; Markless \& Streatfield, 2006). For an example of how the balanced scorecard has been implemented in a library, see http://www2.lib.virginia.edu/bsc/index.html.
} 
society as a whole, often in monetary terms to show evidence of impact. ${ }^{6}$ It is at this crossroads between performance and impact that library valuation offers a new and perhaps improved way to demonstrate that libraries really do matter.

Impact now can be considered the key term for understanding library valuation studies. For the purposes of this paper, impact is defined as a net change in the know-how and the behavior experienced by individuals or groups, users or non-users, as a result of the library and its services. This net change can be of any type: short-term or long-term, perceived or actual, positive or negative (Bertot, 2006; Poll, 2012). Libraries have direct and indirect effects (they touch the lives of the people who use them as well as the lives of those who do not) and they have intrinsic and well as extrinsic value (Town, 2011). Impact will vary greatly from individual to individual because public libraries have diverse stakeholders, each with their own set of expectations, motivations, and abilities. Due to the multiplicity of ways in which a wide range of individuals experience the impact of the library, assigning worth or value to that impact is the subject of much debate. Accordingly, scholars have developed several different frameworks through which library valuation studies are performed.

\section{The Valuation Methods}

For simplicity, valuation domains can be categorized into those that produce a direct benefit figure and those that provide an indirect benefit figure. These figures are sometimes articulated as "use" and "non-use" values respectively (Aabø \& Audunson, 2002). Direct benefits/use values can be either tangible or intangible and are used to talk about the ways an individual benefits from visiting the library, such as increased fluency with an on-line database. Indirect benefits /non-use values cover the tangible and intangible ways that third parties or the entire population benefit, such as the sense of satisfaction that libraries exist (regardless of whether or not the individuals actually use the library) (Aabø, 2002). Aabø and Audunson (2002) further this explanation, stating that taken together, the direct/use-values and the indirect/non-use values combine to create total value. Hence, it is important to capture both direct and indirect values in order to discuss the full effect libraries have on their community.

The econometric models produce either direct or indirect values, and some are capable of showing the combined, or total, value. The most common econometric methods include cost-benefit-analysis, return-on-investment, and contingent valuation. Cost-benefit-analysis (CBA) is a policy-analysis tool used to evaluate the potential benefit of a policy, project, or service in terms of a ratio

\footnotetext{
${ }^{6}$ Indications of the library's impact may include things like successful completion of homework assignments, getting a job that was applied for on-line at the library, and more generally, saving time and money.
} 
between cost and benefit (Kim, 2011). Library valuation studies employ CBA to demonstrate the degree to which the benefit of public libraries outweighs the cost incurred in delivering the services (Chung, 2008). CBA works well to define direct dollar benefits to taxpayers but values are derived from a singular service or collection item, and therefore the method cannot estimate the value of the library as a whole (Imholz \& Arns, 2007). Return-on-investment (ROI) is similar to CBA in that it is a ratio of cost to benefit, but ROI is concerned with showing the result of an investment and is applied at the end to ascertain the result of a certain investment, policy, project decision, or action, rather than at the beginning to help make a decision (Kim, 2011).

Contingent valuation $(\mathrm{CV})$ is the predominant method for determining a more holistic value of the library. By using stated preferences from questionnaires or interviews with the patron instead of revealed preferences that require researchers to observe patrons utilizing one specific library service at a time, CV is seen as capable of deriving both direct and indirect value. Originally designed to obtain a financial value for non-profit services and organizations without an established market value, contingent valuation relies on asking people what they would be willing to pay for various library services and benefits or what they would be willing to accept in exchange for those services or benefits (Poll, 2012). The method is used extensively in environmental economics and increasingly in education, social services, arts, culture, and now libraries (Carson, Flores, \& Meade, 2001; Hughes, 2009; Imholz \& Arns, 2007). Researchers rely on contingent valuation for its ability to estimate total value, which includes indirect/non-use values. Indirect/non-use values are important in libraries because many of the library's social impacts, such as social inclusion, early and continuing education, and cultural heritage preservation, are largely indirect. Such indirect impacts can potentially affect entire communities by creating a more cohesive, educated and productive pool of community members, which benefits both current and future generations (Poll, 2012). Richard Carson (2001), a prominent University of California San Diego economist working on environmental valuation, puts it succinctly: "[one] need not directly use a good to get utility from it" (p. 175). Carson refers to the idea that people value natural phenomena "simply for its existence." (Consider the Grand Canyon or the unrivaled biodiversity of the marine environment.) Therefore, a price can be created around the "vicarious enjoyment" of nature through a figure derived from the public's willingness to pay for the government to maintain that natural landscape. The library analogy is well-known: people tend to value the library's existence regardless of their own library use patterns, believing simply that every town should have a library (Aabø \& Audunson, 2002; De Rosa \& Johnson, 2008). Thus, contingent valuation is a survey methodology that can be used to obtain 
both direct and indirect dollar values for the library and its services, arguably providing a total value figure.

True Value: Validity Issues and Different Frameworks for Assessing Value

Americans for Libraries Council's 2007 library valuation report, Aabø's 2009 meta-analysis, and Kim's 2011 critical review, as well as many other smallerscale works, have explored these aforementioned valuation methods in detail, illuminating a trend of adopting econometric tools formerly reserved for business and industry in order to measure library value. Library valuation methods have become increasingly refined over the past fifteen years, but where is this trajectory headed? On the one hand, there is widespread agreement that "talking dollars makes sense" (Imholz \& Arns, 2007, p. 7). On the other hand, there are known validity problems with the methods, and there is growing recognition that focusing exclusively on monetary values is not effective in capturing the true value of the library (Imholz \& Arns, 2007; Poll, 2012; Sawaya et al., 2011; Streatfield, 2012; Town, 2011).

\section{Methodological Hiccups with Value Assessment}

In her paper outlining discussion items for an International Standards Organization (ISO) standard for library valuation, Poll (2012) laments the methodological glitches inherent in library valuation, asserting that most methods only indicate, but do not prove, the impact of the library. Poll argues that those methods that may prove impact will not always be statistically valid. Likewise, in her meta-analysis of empirical library studies that report an ROI figure, Aabø (2009) discovered a variety of approaches used to arrive at a direct ROI dollar value, including market analogies, surrogate measures, secondary economic impacts, and contingent valuation surveys. While Aabø (2009) asserts that her regression analysis statistics have strong validity due to the homogeneity of the library type studied (most studies covered U.S. public libraries), she notes that the meta-analysis suffers from the multiplicity of measurements and methods used in the various underlying studies. She advises that her analysis should be understood as "preliminary" and "interpreted with caution" for this reason (p. 321).

Even contingent valuation, which is the predominant non-market valuation method, is not without controversy. The reliability of $\mathrm{CV}$ and the relevance of non-use values in cost-benefit-analysis is still a matter of debate (Aabø \& Audunson, 2002; Carson, Flores, \& Meade, 2001; Kim, 2011; Poll, 2012). Indeed, the library valuation literature repeatedly questioned whether contingent valuation can effectively and appropriately be used in the library context. 
Research shows that people form opinions about the library based on attitudes rather than demographics or the extent of library use (Aabø \& Audunson, 2002; De Rosa \& Johnson, 2008). As such, taxpayers' reported willingness to financially support the library is more about their feelings about the library rather than some kind of rational choice decision-making process, which is the basis of economic theory.

Along these lines, CV detractors say that the CV survey method results in an over-estimation of support values because it does not reflect a true rationalchoice economic preference, but rather the respondent's feelings. One such feeling that appears to play a role in library valuation is a sense of "altruism," the feeling behind the commonly-held belief that the library is something to which every member of society is entitled. In valuation calculations, altruism is said to create a warm glow effect, "a feeling of well-being or satisfaction generated by the act of giving" (Lee, Chung, \& Jung, 2010), which contingent valuation critics believe can skew the data towards an over-estimation of the willingness-to-pay. Indeed, a 2008 study of library support in America found that while $78 \%$ of the study's respondents said they would either probably or definitely vote yes to increase funding for the library, library referenda do not actually pass at anywhere near this rate; in fact, passage rates have been in steady decline for years (De Rosa \& Johnson, 2008). In testing the presence of the warm glow effect in contingent valuation, Lee, Chung and Jung (2010) ultimately found that the degree to which the warm glow effect changes respondents' willingness to pay may vary depending on the type of public good being studied. In the context of the public library the warm glow effect is strong and its bias must therefore be removed in order to get an accurate valuation figure. Thus, the contingent valuation method remains controversial in library valuation.

\section{Frameworks for Assessing True Value}

Beyond the methodological validity problems of contingent valuation and other econometrics, many believe that focusing exclusively on monetary values may obscure the library's true value. These critics call for a fuller demonstration of the social benefits bestowed by the library (Imholz \& Arns, 2007; Poll, 2012; Sawaya et al., 2011; Streatfield, 2012; Town, 2011). One method for capturing these social benefits was tested by the U.S. IMPACT studies, a research initiative led by The University of Washington Information School with funding from the Institute of Museum and Library Services (IMLS) and the Bill \& Melinda Gates Foundation. The initiative developed a mixed methods research approach to measure outcomes related to public access computing in public libraries (Becker, Crandall, \& Fisher, 2009). The goal of the influential U.S. IMPACT studies was to investigate how "individuals, families, and communities benefit (with a focus 
on social, economic, personal, and professional well-being) from free access to computers, the Internet, and related services at public libraries" (Becker et al., 2010, p. 20). Working from an "outcomes oriented framework", the study moves beyond anecdotal evidence or purely economic rationale. Instead, the study uses a mixed methods research approach involving telephone and internet surveys to collect generalizable quantitative data and case studies for important contextual information, in order to develop indicators of change in the lives of the library users and the community. The studies' authors believe that such an approach can "help justify budget requests in a policy environment increasingly focused on how individuals and the public benefit from social programs" (Becker, Crandall, \& Fisher, 2009, p. 111). The important leap this research takes is to link library outcomes, or impacts, to specific public policy goals, rather than making a simple, though arguably succinct, economic cost-benefit analysis argument. The U.S. IMPACT studies align library services and programs with the pressing interests of local leadership. In their attempt to find a connection between libraries, in this case through a focus on public access computing, and larger social goals, including civic engagement, eBusiness, education, eGovernment, public health, employment, and social inclusion (Becker, Crandall, \& Fisher, 2009, p. 112), the U.S. IMPACT studies represent a leap forward in the trajectory of library valuation.

Similarly, grantees of the Global Library Initiative (GL) of the Bill \& Melinda Gates Foundation, found that using a range of empirical impact evidence works best to illustrate the role of libraries in the realization of key social goals committed to by local government and public policy officials (Sawaya et al., 2011). By combining both data and stories, GL grantees' valuation studies aim to provide a nuanced demonstration of library value that makes a compelling correlation between the act of funding libraries and the ability to achieve public policy goals. The Global Library Initiative calls its approach "evidence-based advocacy," where a full range of evidence (both economic and social metrics) is marshaled to encourage sustained funding support and the development of community partnerships and to entice new users into the library. This kind of case-by-case evidence-demonstration may be just the kind of tailored approach that library managers can use to create meaningful advocacy products, such as evidence-based briefs, and to forge an ongoing dialog between library professionals and the local community (Imholz \& Arns, 2007).

Underlying this evidence-searching lies the persistent notion that the real impact of libraries on people and in communities is mostly intangible, making it difficult to monetize their value. J. Stephen Town argues that current frameworks of library valuation do not provide compelling demonstrations of worth (2011). He suggests that current methods measure libraries against goals, when instead valuation should zero in on the principles or ethics that arise out of our value 
system. For Town, worth is created by the combination of value plus impact. Town (2011) calls for deeper thinking and a broadening of value-statements that will enable the measurement of the intangible value-added benefits of the library-not service quality, not narrow return-on-investment/cost-effectiveness, not efficiency, not user satisfaction, not staff capability, but rather, what the library can do within its own walls and beyond. These intangible benefits include the partnerships the library forges, the novel ideas it enables, ${ }^{7}$ and the social hub it creates. For this, Town argues, "it's likely that the [evidence] will be largely based on narrative rather than through numbers alone" (2011, p. 124).

Thus, there are a number of frameworks through which library value is assessed and measured. They all point to a trajectory of library valuation that began with an emphasis on the monetization of library value and then increasingly incorporated stories and case-studies to provide evidence of true impact. From there, library valuation has begun evolving toward an evidence-based, impactcentric advocacy paradigm. There is now widespread agreement that to tell a convincing story of how truly embedded the library is in the socio-economic life of the community, we cannot rely on monetary values alone. Instead, the valuation of the library must always incorporate some kind of evidence of impact. However, while the newest buzzword in library valuation may be evidence-based advocacy, to what extent have valuation studies been an effective advocacy tool?

\section{Library Valuation Studies and Advocacy}

Like the gap often witnessed between the research and practice arms of the library and information science (LIS) field, there appears to be a disconnect between library research and library advocacy. The Public Library Association (PLA) offers an Advocacy Mini-Toolkit in their 2009 PLA Reader for Public Library Directors and Managers, which consists of "information-packed excerpts and articles" (p. 47) that will help professionals demonstrate the value of their library. Despite this description, however, nowhere in this toolkit is there any mention of economic valuation techniques, publicly available return-on-investment calculators, or contingent valuation research (Hughes, 2009, Part II). This shows that it cannot be assumed that all valuation efforts are part of a larger advocacy plan. Imholz and Arns (2007) suggest the existence of two separate but parallel

\footnotetext{
${ }^{7}$ For an interesting discussion of how libraries aid in idea-creation and to learn about a unique way of measuring how the library helps people accomplish personal goals, see Aaron Schmitt's November 9, 2009 blog entry, Libraries Should Become Better with Use (Retrieved from http://www.walkingpaper.org/2399). Schmitt proposes the Library Made icon that highlights how specific library resources, programs, and staff have enabled people to achieve certain tasks and bring their ideas to fruition. More than a success story link, the icon works like trackbacks for library content, helping to make a direct and measureable connection between the library and its stakeholders.
} 
trends: library advocacy efforts are becoming more strategic and wider in scope and valuation research methodology has become increasingly sophisticated. Imholz and Arns do not, however, see these two trends as having successfully merged yet:

To date, there has been very little planning of studies that could support national advocacy, almost no investment in the conversion of data for advocacy purposes, and almost no follow-up on the advocacy results of the new crop of economic valuation studies (p. 30).

Library advocacy efforts appear to be largely piecemeal and have been subject to well-founded criticism. In a stinging critique of advocacy research findings, Lyons (2007) asserts that the library profession needs to be more careful when constructing claims for advocacy campaigns and evaluating library research. He cites some meaningless claims in The American Library Association's (ALA) Quotable Facts campaign: ${ }^{8}$

$>$ There are more public libraries than McDonalds in the United States.

$>$ Reference librarians in the nation's public and academic libraries answer nearly 6.6 million questions weekly. Standing single file, the line of questioners would span from Ocean City, MD to Juneau, AK.

$>$ Americans spend nearly three times as much on candy as they do on public libraries.

(American Library Association, 2012)

Would it not be more effective to center an advocacy campaign around a number, or monetary value, that pinpoints the degree to which the benefits of public libraries outweigh the costs incurred in delivering the services? Lyons' argument is that ALA's points are not only irrelevant, but they also prove that the library profession "is at a loss for meaningful ways in which to interpret library statistics" (2009, p. 214).

In a critical review of library valuation studies, Giyeong Kim (2011) distilled a large variety of methods and purposes down to two different end games: communicating value or predicting performance. Based on these divergent goals, it seems clear that not all library valuation studies are undertaken for the purposes of library advocacy. The two frameworks identified by Kim (2011) are the marketing framework, used to communicate value, and the evaluation framework, used to predict performance. Kim's articulation of two distinct frameworks is an example of how measuring performance and measuring

\footnotetext{
${ }^{8}$ These claims are still being advertised on ALA's website as of this writing.
} 
impact both fall under the guise of library valuation, but both are not equally suited for library advocacy.

The marketing framework can be understood as having an advocacy purpose by prioritizing communication between the library and its stakeholders. This framework encourages library managers, library patrons, and library funders to talk to each in order to unearth preferences and keep stakeholders actively engaged in the library. In this framework, libraries use the process itself to show stakeholders the value of the library. In this scenario, an appropriate return-oninvestment is developed between library staff/researchers and library stakeholders/funders by coming up with an acceptable economic value based on assumptions that all stakeholders buy into (Kim, 2011). In contrast, Kim asserts that the evaluation framework describes the current state of the library and predicts its future performance, more appropriate for strategic planning, process management, staff development, and comparing libraries with each other than for advocacy to stakeholders.

\section{A Better Way of Proving Themselves}

As discussed, there is widespread agreement that public libraries are worth their cost, but that libraries must find a better way of proving their worth. Social return-on-investment has the potential to address the social impacts of the library in a powerful way, although the SROI method has been employed too little in library valuation to evaluate its usefulness on a meaningful scale. In addition, social return-on-investment is subject to the same obstacles facing the widespread adoption of library economic valuation reporting: limited funding for the studies, the need for additional training; non-existent, incomplete, or inaccessible datasets; and no standardization of methods and terminology (Imholz \& Arns, 2007; Markless \& Streatfield, 2006; Poll, 2012). Such obstacles are beyond the scope of this paper, but it should be understood that they are significant.

Nevertheless, social return-on-investment and related reporting practices from the business world may turn out to be just the thing library advocates need. Imholz and Arns (2007) call for a "national valuation reporting framework" (p. 34), along the lines of what has taken place in the business world through the Global Reporting Initiative (GRI). The GRI is a 30,000 member-strong organization that produces guidelines for annual financial reports that measure a company's economic, environmental, social, and governance performance (Global Reporting Initiative, n.d.). Looking to gain a competitive edge, companies want to show an increasingly demanding public that they care about the environment, take care of their employees and the local community, and practice good governance, in addition to making a profit. When it started, GRI's idea was that widespread adoption of triple-bottom-line reporting (economic, 
social, environmental, and now governance, performance metrics), could potentially institutionalize corporate social responsibility. The Global Reporting Initiative now has members from outside of business and industry, including academia, labor, public agencies, and intergovernmental agencies, all with a stake in demonstrating their value in the broadest terms (Global Reporting Initiative, n.d.). The growth of this kind of reporting has two consequences that are important for library advocacy (Imholz \& Arns, 2007). First, accounting for externalities is increasingly seen as both necessary and (to a lesser degree) beneficial. Second, the availability of more social and environmental performance data is contributing to the growth of socially responsible investing.

As such, library advocates would have much to gain from using SROI protocols and entering into the Global Reporting Initiative fold. The ability to produce a report that accounts for both social and economic value in a format recognized and utilized by both the private and public sector would put public libraries in the running for new investment (Imholz \& Arns, 2007). Annual reports with SROI data would allow socially responsible investors and/or traditional sources of library funding to make meaningful comparisons between different organizations' contribution to social welfare and their efficiency in doing so. Theoretically, it would enable investors to clearly identify the most socially and fiscally efficient organizations from either the public or the private sector (Imholz \& Arns, 2007). During a time of constrained budgets where competition amongst public service providers is high, this kind of reporting structure would facilitate fair and effective budget allocations. In this scenario, it is likely that public libraries would emerge as competitive players in a new landscape that compares organizations along the socio-economic value-add dimension, rather than on profits alone.

\section{Conclusion}

The degree to which library economic valuation can effectively measure the full impact of the public library on society as a whole is still a matter of debate. It is clear that valuation methodology has become increasingly complex, with techniques that are able to derive economic value from non-market goods and also account for a broader range of social impacts. However, there is a consensus that numbers alone will never fully address the total value of libraries to society. In addition, it remains to be seen, or even investigated at a significant level, if economic valuation studies are actually successful in advocating for increased library spending (Imholz \& Arns, 2007). Thus, while we do not yet know the extent to which valuation studies and the trend toward the monetization of library outcomes positively affect the advocacy effort, it is widely recognized that the social benefits of the library must be part of the equation. As Town (2011) 
suggests, "compelling proof will reside in transcendent contribution beyond immediate temporal, spatial, and influential boundaries of libraries" (p. 111). Already, such boundaries are being pushed by visionary ideas of what the library is and does. For example, Makerspaces in libraries align with federal goals to engage young people in science and engineering; the StoryCorps program turns public libraries into recording studios; Virtual Reference provides librarian assistance anywhere at any time; healthcare workers on staff at libraries tackle public health issues; public access computing helps close the digital divide and becomes a lifeline for both rural populations and victims of natural disasters. The reach of libraries is far and wide, and libraries' value to society is tied up in their ability to be at once a source of entertainment, collaboration, education, support, and innovation.

This paper has outlined the trajectory of library economic valuation, touching on the developments that have led researchers and advocates on a search for new ways to articulate the tremendous socio-economic value the public library brings to our communities. Tracing this trajectory has uncovered the need to create a few bridges: 1) unite library valuation efforts and advocacy plans; 2) link library services to the achievement of public policy goals; and 3) connect public libraries to a wider funding base through the Global Reporting Initiative. To carry the conversation further, more research is needed to decipher the success of library economic valuation research on library advocacy (Imholz \& Arns, 2007). It could be useful to take a closer look at those libraries that have undertaken a valuation study to see if there is a discernible pattern of implementation. Are some libraries better candidates for valuation studies than others, and how might this affect widespread adoption of a national advocacy plan anchored with standardized valuation reporting? Furthermore, it may be fruitful to explore the roll of the Bill \& Melinda Gates Foundation in uniting library valuation efforts and advocacy plans. To the extent that the foundation is a major funder of both public access computing in libraries and library valuation research, as well as being a successful champion of library advocacy, the organization is poised to play a vital role in developing a national advocacy plan that focuses largely on public access computing. ${ }^{10}$ What kind of effects would we see if library valuation research and library advocacy were filtered through a public access computing

\footnotetext{
${ }^{9}$ For more information on the vital role public libraries play as agents of e-government and as providers of free internet access, see the Vol. 11, Number 9- 4 September 2006 First Monday article from Bertot, Jaeger, Langa and McClure: http://www.firstmonday.org/htbin/cgiwrap/bin/ojs/index.php/fm/article/view/1392/1310

${ }^{10}$ The Bill \& Melinda Gates Foundation has been the single largest source of private funding for libraries since its 1997 program that spent $\$ 200$ million in an effort to bridge the digital divide in the U.S (Gale, 2012).
} 
lens? In a time where the public library faces accusations of irrelevance and the continued threat of budget cuts, the widespread availability of internet access in the public library may be just what the library needs to provide concrete evidence of its socio-economic impact and thereby make the case for its continued existence.

\section{References}

Aabø, S. (2009). Libraries and return on investment (ROI): A meta-analysis. New Library World, 110(7), 311-324. doi: 10.1108/03074.800910975142

Aabø, S., \& Audunson, R. (2002). Rational choice and valuation of public libraries: Can economic models for evaluating non-market goods be applied to public libraries? Journal of Librarianship \& Information Science, 34(1), 515. doi: 10.1177/096100060203400102

American Library Association. (2012). Quotable facts about American libraries. Retrieved November 17, 2012, from http://www.ala.org/offices/sites/ala.org.offices/files/content/QuotableFacts.2 $\underline{012 \_0 . p d f}$

Becker, S., Crandall, M. D., Fisher, K. E., Kinney, B., Landry, C., \& Rocha, A. (2010). Opportunity for all: How the American public benefits from internet access at US libraries. (Research). Washington D.C.: Institute of Museum and Library Services. Retrieved from http://www.eric.ed.gov/ERICWebPortal/search/detailmini.jsp?_nfpb=true\&_ \&ERICExtSearch_SearchValue_0=ED510740\&ERICExtSearch_SearchType O=no\&accno=ED510740

Becker, S., Crandall, M. D., \& Fisher, K. E. (2009). Communicating the impact of free access to computers and the internet in public libraries: A mixed methods approach to developing outcome indicators. Public Library Quarterly, 28(2), 109-119. doi: 10.1080/01616840902892309

Bertot, J.C., Jaeger, P.T., Langa, L.A., McClure, C.R. (2006). Public access computing and internet access in libraries: The role of public libraries in egovernment and emergency situations. First Monday (Online), 11(9)

Bertot, J.C. (2006). Outcomes-based evaluation in public libraries: From online instruction to practice. The Library Quarterly, 76(2), 241-245. Retrieved from http://www.jstor.org/stable/10.1086/506578 
Carson, R. T., Flores, N. E., \& Meade, N. F. (2001). Contingent valuation: Controversies and evidence. Environmental and Resource Economics, 19(2), 173-210. doi: http://springerlink.metapress.com/link.asp?id=100263

Chung, H. K. (2008). The contingent valuation method in public libraries. Journal of Librarianship and Information Science, 40(2), 71-80.

De Rosa, C., \& Johnson, J. (2008). From awareness to funding a study of library support in america: A report to the OCLC membership Online Computer Library Center (OCLC).

Durrance, J. C., \& Fisher-Pettigrew, K. E. (2002). Toward developing measures of the impact of library and information services. Reference \& User Services Quarterly, , 43-53.

Externalities. (n.d.). In BusinessDictionary.com. Retrieved November 17, 2012, from http://www.businessdictionary.com/definition/externalities.html

Externality. (n.d.). In investopedia.com. Retrieved November 17, 2012, from http://www.investopedia.com/terms/e/externality.asp\#axzz2DlxKVyO5

Gale Directory of Company Histories (2012). Bill \& Melinda Gates Foundation. Retrieved November 21, 2012, from http://www.answers.com/topic/bill-andmelinda-gates-foundation

Global Reporting Initiative. (n.d.). About GRI. Retrieved November 27, 2012, from https://www.globalreporting.org/information/about-gri/what-isGRI/Pages/default.aspX

Hughes, K. M. (Ed.). (2009). The PLA reader for public library directors and managers. New York: Neal-Schuman Publishers, Inc. doi: 31223088632139

Imholz, S., \& Arns, J. W. (2007). Worth their weight: An assessment of the evolving field of library evaluation. Public Library Quarterly, 26(3), 31-48. Retrieved from http://search.ebscohost.com/login.aspx?direct=true\&db=llf\&AN=502902928 $\underline{\& \text { site}=\text { ehost-live }}$

Institute of Library and Museum Services. (n.d.). About. Retrieved October 15, 2012, from http://www.imls.gov/about/21st_century_skills_home.aspx 
Jaeger, P. T., Bertot, J. C., Kodama, C. M., Katz, S. M., \& DeCoster, E. J. (2011) Describing and measuring the value of public libraries: The growth of the internet and the evolution of library value. First Monday (Online), 16(11), 114.

Kim, G. (2011). A critical review of valuation studies to identify frameworks in library services. Library \& Information Science Research (07408188), 33(2), 112-119. doi: 10.1016/j.lisr.2010.09.006

Lee, S., Chung, H., \& Jung, E. (2010). Assessing the warm glow effect in contingent valuations for public libraries. Journal of Librarianship \& Information Science, 42(4), 236-244. doi: 10.1177/0961000610380819

Lyons, R. (2009). Critiquing advocacy research findings: An illustration from the OCLC report, from awareness to funding: A study of library support in America. Public Library Quarterly, 28(3), 212-226.

Markless, S., \& Streatfield, D. (2006). Evaluating the impact of your library. London: Facet.

Poll, R. (2012). Can we quantify the library's influence? Creating an ISO standard for impact assessment. Performance Measurement \& Metrics, 13(2), 121130. doi: $10.1108 / 14678041211241332$

Sawaya, J., Maswabi, T., Taolo, R., Andrade, P., Grez, M., Pacheco, P., . . . Kochanowicz, M. (2011). Advocacy and evidence for sustainable public computer accessExperiences from the Global Libraries Initiative. Library Review, 60(6), 448-472. doi: 10.1108/00242531111147189

Streatfield, D. (2012). Impact Planning and Assessment of public libraries: a country level perspective. Performance Measurement \& Metrics, 13(1), 8-14. doi: $10.1108 / 14678041211228535$

Town, J. S. (2011). Value, impact, and the transcendent library: Progress and pressures in performance measurement and evaluation. Library Quarterly, 81(1), 111-125. Retrieved from http://search.ebscohost.com/login.aspx?direct=true \&db=1lf\&AN=503008482 $\underline{\& \text { site }=\text { ehost-live }}$ 